九州大学学術情報リポジトリ

Kyushu University Institutional Repository

\title{
TEISO ESAKI (1899-1957)
}

Hirashima, Yoshihiro

https://doi.org/10.5109/2501

出版情報: ESAKIA. 26, pp. 1-4，1988-01-25. Entomological Laboratory，Faculty of Agriculture， Kyushu University

バージョン:

権利関係: 


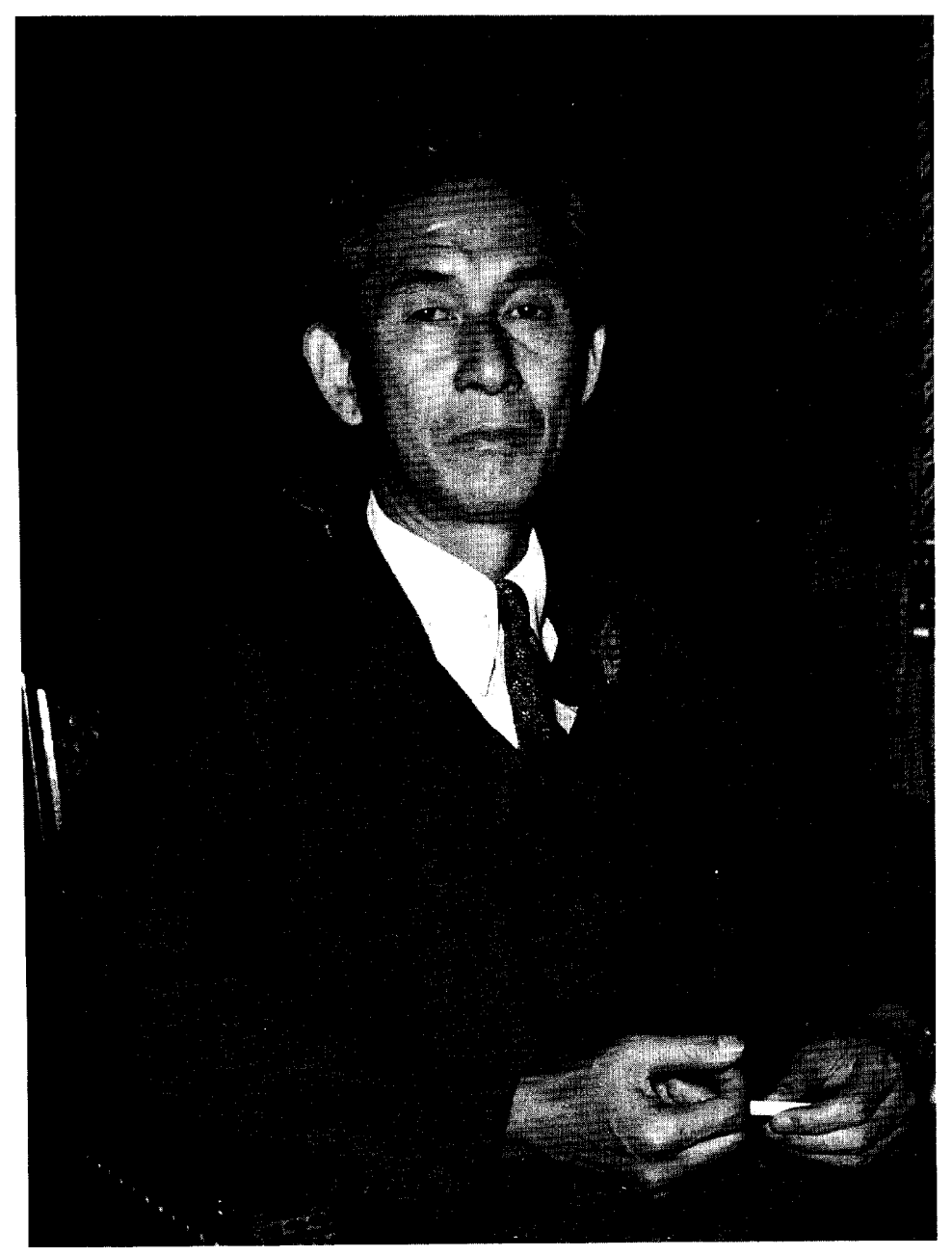

TEISO ESAKI (1899-1957) 
ESAKIA, (26) : 1-4. 1988

\title{
TEISO ESAKI (1899-1957)
}

\author{
Y. HIRASHIMA
}

Thirty years have passed since Professor Teiso Esaki departed this life. I was privileged to have his personal guidance since I matriculated at Kyushu University (then Kyushu Imperial University) in 1946. Professor Esaki was the chairman of the Entomological Laboratory of the Faculty of Agriculture, and was appointed as dean of the Faculty of Agriculture in June of 1948, while concurrently holding the laboratory chairmanship. Despite his busy daily life, his guidance to us as students was warm and sincere and he was an excellent teacher.

Professor Esaki had a serene and kind personality. A born linguist who had mastered English, German, French, Italian and Hungarian as well as Esperanto, he was an erudite man with a retentive memory and was conversant with entomology, zoology and the history of biology. He was held in high repute by many.

Professor Esaki's contribution to academic circles can be broadly classified in six areas. The first is, his achievements in his own chosen field of study. While his specialty was taxonomy of Hemiptera, he particularly loved butterflies. He established CHORUI DOKOKAI (蝶類同好会, the Society of Butterfly Lovers) in 1929 and began publishing a journal called "Zephyrus". One of his important contributions to the Hemiptera is a monograph of the Helotrephidae published in 1928 with W. E. China (Eos, 4 : 129-172). He was also well informed on zoogeography, and a paper "A zoogeographical consideration of the insect fauna in the Pacific Islands" (Proc. 8th Intern. Congr. Ent. : 372379, 1950) was one of his accomplishments. In particular, Professor Esaki was a man of first rank in the discipline of the history of entomology. His theses and enlightened writings probably totalled nearly 800 (Esakia, (6) : 1-26, 1967). One of his unforgettable contributions was the planning, editing and publishing of NIPPON KONCHU ZUKAN (日本昆虫図鑑, Iconographia Insectorum Japoni corum), the first edition (2241 pp.) in 1932 and the second edition (1738 pp.) in 1950.

The second area benefitting from his dedicated efforts was that of the academic societies. Professor Esaki was concurrently a councilor of the Zoological Society of Japan, the Entomological Society of Japan, the Japanese Society of Applied Entomology and Zoology, etc., and was president of the Entomological Society of Japan from 1951 until his death. Just two months before he passed away, he had, in this latter capacity, provided His Majesty the Emperor with information on insects.

His meritorious deeds in raising to a world level the education of amateur entomologists was a third area of strength. Professor Esaki was utterly indifferent to the academic clique and willingly assisted and gave advice without discrimination to any professional or amateur insect lover. There remain many people today who well remember this admirable virtue which was such a true part of him.

The fourth area in which his contribution is notable is the collection of entomological books and literature he amassed, most of which is now housed in the Esaki Library in Kyushu University. During his 5 years of study in Europe from 1924-28, he bought a great many foreign books (especially 
European), and continued to add domestic and other valuable literature until his death.

His collection of insect specimens is his fifth legacy. A foundation of the Kyushu University Insect Collection was formed by Professor Esaki and his co-operators. It includes the Micronesia Collection which is composed of specimens collected and arranged from his own explorations. The Micronesia Collection of Kyushu University is especially noted among the society of entomologists.

The sixth area in which this memorable man is well remembered is in those he left behind. Individuals who were trained directly by Professor Esaki in Kyushu University have played important roles as scholars, educators and researchers ; some have retired or passed away while many others remain active today. These Kyushu University entomology graduates whom he trained and who follow in his footsteps are listed below. (The year of graduation is shown in parenthesis.)

J. Masaki (正木十二郎),(1930), former Director, Department of Environmental Science, National Kanto-Tosan Agricultural Experiment Station.

†A. Yokoyama (横山淳夫),(1930), Emeritus Professor of Biology, Kagoshima University.

†C. Takeya (武谷直),(1931), former Professor of Biology, Kurume University.

$\dagger$ K. Yasumatsu (安松京三),(1933), Emeritus Professor of Entomology, Kyushu University.

K. Nomura (野村健-一),(1937), Emeritus Professor of Entomology, Chiba University.

S. Yoshimura (吉村清一郎),(1941), former Director, Department of Entomology and Plant Pathology, Fukuoka Prefectural Agricultural Experiment Station.

T. Shirôzu(白水隆),(1941), Emeritus Professor of Biology, Kyushu University.

†I. Fukushima (福島一雄),(1943), died in battle in World War II.

M. Mochizuki (望月正己),(1943), former Director, Toyama Prefectural Agricultural Experiment Station.

M. Moritsu (森津孫四郎), (1943), Emeritus Professor of Entomology, Yamaguchi University.

S. Ito (伊藤修四郎), (1944), Emeritus Professor of Entomology, University of Osaka Prefecture.

T. Tachikawa (立川哲三郎), (1947), Professor of Entomology, Ehime University.

K. Matsuo (松尾寛一),(1947), former Director, Oita Prefectural Sericultural Experiment Station.

H. Kuroko (黑子浩),(1948), former Professor of Entomology, University of Osaka Prefecture.

M. Kobayashi (小林勝利),(1948), Insect Physiologist ; Director General, Lotte Central Laboratory, Lotte Co. Ltd.

M. Sasakawa (笹川満廣),(1948), Professor of Entomology, Kyoto Prefectural University.

I. Takaoka (高岡市郎),(1948), former Director, Central Research Institute, Japan Tabacco Corporation.

K. Yasutomi (安富和男), (1947-51, 旧制大学院), former Medical Entomologist-in-charge, Department of Medical Entomology, National Institute of Health, Tokyo.

T. Kaku (加来俊則), (1948-50, 旧制大学院), former Assistant Director, Department of Commercial and Industrial Development, Fukuoka Prefectural Government.

Y. Hirashima (平嶋義宏), (1949), Professor of Entomology, Kyushu University.

K. Umeda (梅田兼弘),(1950), former Research Scientist-in-charge, Shell Chemical Co. Ltd., Fujisawa City.

M. Tanaka (田中学),(1950), former Chief Entomologist, Kuchinotsu Branch, Fruit Tree Research Station, Ministry of Agriculture, Forestry and Fisheries.

†R. Matsuda (松田隆一),(1950), Insect Morphologist ; Biosystematics Research Center, Agriculture 
Canada, Ottawa.

A. Nagatomi (永冨昭),(1951), Professor of Entomology, Kagoshima University.

K. Ogata (緒方一喜),(1953), Medical Entomologist; Standing Director, Japan Environmental Sanitation Center, Kawasaki City.

S. Nakao (中尾舜一),(1953), Professor of Biology, Kurume University.

S. Yamamoto (山本慎二郎),(1953), Director, Research Section, Kyushu Sankyo Co. Ltd., Tosu City.

H. Fukuda (福田浩),(1954), Teacher of Biology, Fukuoka Chuo High School.

†I. Hiura (日浦勇),(1955), Evolutionary Biologist and Entomologist-in-charge, Osaka Museum of Natural History.

T. Yoshida (吉田智昭),(1955), Teacher of Biology, Kokura Nishi High School.

Y. Maeda (前多良彦), (1953-55, 旧制大学院), Teacher of Biology.

M. Takahashi (高橋三雄), (1955, MC), Director, Department of Medical Entomology, National Institute of Health, Tokyo.

S. Kimoto (木元新作), (1956), Professor of Biology, Kurume University.

Y. Murakami (村上陽三),(1956), Associate Professor of Entomology (Biological Control), Kyushu University.

K. Morimoto (森本桂),(1956), Associate Professor of Entomology, Kyushu University.

K. Kawashima (/川島健治郎), (1956, MC), Professor of Biology, School of Health Sciences, Kyushu University.

T. Hidaka (日高輝展), (1956, MC), Chief, Laboratory of Insect Behavior, Division of Entomology, National Institute of Agro-Environmental Sciences, Tsukuba.

T. Kifune (木船悌嗣), (1957, MC ; 1960, DC), Professor of Parasitology, Fukuoka University.

H. Sasaji (佐々治寛之), (1958), Professor of Biology, Fukui University.

T. Saigusa (三枝豊平),(1959), Professor of Biology, Kyushu University.

M. Sonda (尊田望之),(1959), Director, Nagoya Plant Protection Station, Ministry of Agriculture, Forestry and Fisheries.

R. Ishikawa (石川良輔), (1959, MC ; 1962, DC), Professor of Biology (Natural History), Tokyo Metropolitan University.

K. Yano (矢野宏二), (1959, MC; 1962, DC), Professor of Entomology, and Dean, Faculty of Agriculture, Yamaguchi University.

Y. Hirose (広瀬義躬),(1960), Associate Professor of Entomology (Biological Control), Kyushu University.

Y. Maeta (前田泰生),(1960), Associate Professor of Entomology, Shimane University.

Y. Miyatake (宮武頼夫),(1960), Entomologist-in-charge, Osaka Museum of Natural History.

Others who studied under Professor Esaki at Kyushu University include :

$\nmid$ †. Hori (堀 浩), former Research Associate in Entomology, Kyushu University.

Frank Ho (何国模), in USA.

T. Ishihara (石原保), Emeritus Professor of Entomology, Ehime University.

Y. Kurosawa (黑澤良彦), former Director, Department of Zoolgy, National Museum of Natural History, Tokyo.

†T. Yokoo (横尾多美男), Professor of Entomology, Saga University. 
A. Yamasaki (山崎 昭), former Deputy Director, Yokohama Plant Protection Station, Ministry of Agriculture, Forestry and Fisheries.

C. Okuma (大熊千代子), Arachnologist ; Research Associate in Entomology, Kyushu University.

S. Miyamoto (宮本正一), Professor of Biology, Chikushi Jogakuen Junior College, Dazaifu City ; former Professor of Biology, Kyushu University.

H. Yamamoto (山本英穂), Head, Section of Biological Science, Fukuoka Environmental Research Center.

R. Morimoto (守本陸也), former Chief Entomologist, Takeda Chemical Co. Ltd.

T. Takara (高良鉄夫), former President of University of the Ryukyus.

T. Torii(鳥居西蔵), former Professor of Entomology (Biological Control), Kyushu University.

K. Nohara (野原啓吾), Professor of Entomology, Kyushu Tokai University.

A biography of Professor Esaki written by Dr. W. E. China appeared in the Entomologist Monthly Magazine (94 (8) : 132, 1958), and one by Dr. J. L. Gressitt was published in the Annals of the Entomological Society of America (57:410-411, 1958). 